Food, Dairy and Home Economic Research

http:/www.journals.zu.edu.eg/journalDisplay.aspx?Journalld=1\&queryType=Master

\title{
CHEMICAL, PHYSICAL AND SENCORY PROPERTIES OF FROZEN CHICKEN BURGER SUBSTITUTED WITH CHICKEN BY-PRODUCTS
}

\author{
Samar M.A. Eid", M.A. Rabie, Gehan A. El-Shourbagy and S.E.A. El-Nemr \\ Food Sci. Dept., Fac., Agric., Zagazig Univ., Egypt
}

\section{Received: 18/10/2017 ; Accepted: 28/11/2017}

\begin{abstract}
The present study aimed to develop an acceptable quality chicken burger by incorporation of poultry by-products i.e., (heart, gizzard, liver, abdominal fat and skin) at a level of $20 \%$. The resultant burger samples were analyzed for physicochemical properties and sensory evaluation during storage up to 6 months. The obtained results indicated that there was a gradual decrease in moisture and protein contents of all burger samples during frozen storage. Whereas, control burger (CB) had the highest value $(67.00 \%)$ but burger contained fat (FB) showed the lowest value $(63.10 \%)$ of moisture content. $(\mathrm{CB})$ contained the highest value $(17.00 \%)$ but $(\mathrm{FB})$ contained the lowest value $(13.55 \%)$ of protein content. There was an increasing in water holding capacity WHC and ash contents during frozen storage period whereas (CB) contained the highest value (3.50) but (FB) contained the lowest value (3.12\%) of ash content. (FB) contained the highest value $(68.87 \%)$ but liver burger (LB) contained the lowest value $(54.03 \%)$ of WHC.Moreover, there was an increasing in cooking loss in all samples during frozen storage. At the end of freezing storage, the results indicated that incorporation of gizzard and heart $(20 \%)$ in chicken burgers showed the best organoleptic properties as compared to the control burger samples. It is also observed that incorporation of $20 \%$ heart and gizzard exhibited higher sensory scores and physicochemical properties. The sensory scores of all tested attributes declined significantly with the progress of storage period.
\end{abstract}

Key words: Chicken burger, chicken by-products substituted, physicochemical characteristics, sensory properties.

\section{INTRODUCTION}

The increasing in the production of broilers followed by increasing in the quantities of offal's especially gizzards with high percentages of proteins and fats, which can contribute for human consumption. However, the high contents of fat makes gizzards tasty with pleasant flavour and popular to the consumer. Depending on the cultural context, offal's may be considered as waste material that is thrown away, or as delicacies that command a high price. The gizzards are muscular organ used for grinding and mixing of the food materials in preparation for digestion, thus replacing the mastication function of the teeth. The strength of the gizzard muscle and tough leather-like lining

\footnotetext{
* Corresponding author: Tel. : +201006444604

E-mail address: samareidsamar@gmail.com
}

allow utilization of grit as well as the feed particles producing much friction in the grinding process. The physical breakdown of large feed particles increases their surface area, allowing more complete enzymatic digestion (Maiti and Ahlawat, 2011). Gizzards are consumed in several countries especially Asian countries. Many products are processed from gizzards, for example, in China, fermented sausage, and dried gizzrards are produced. In Jordon sandwiches are prepared from gizzards. The Sudanese and Egyptian utilize gizzards traditionally in various ways, one of these ways is to be fried with its own fat, or using the abdominal fat of chicken, after addition of some herbs. They also use another method in which gizzards are cooked with other giblets of chicken like livers, hearts, 
and neck, abdominal fat of chicken, plus onions, garlic, and several types of herbs added (Elkhatim et al., 2014).

Poultry meat is comprised of about 20 to $23 \%$ protein, which comminuted products, such as frankfurters, bologna and sausages that typically contain about 17 to $20 \%$ protein, 0 to $20 \%$ fat and 60 to $80 \%$ water (Smith, 2001).

Poultry meat is also more popular to the consumer market because of advantages such as easy digestibility and acceptance by the majority of people and it contains all essential amino acids, a lot of minerals as sodium, potassium, calcium, iron, phosphorus besides traces of vitamins such as vitamin B12 and niacin required for maintaining life and promoting growth. It also characterized by a lower calorific value as it contains less fat which is rich in unsaturated fatty acids (Grześkowiak et al., 2001; Yashoda et al., 2001; FAO, 2014).

Poultry fat can be considered as a source of monounsaturated fatty acids (MUFA) since they constitute $45 \%$ to $50 \%$ of poultry fat (Lee and Foglia, 2000). Many efforts have been made to improve the quality and stability of burger because consumer demand for fast food has been increasing rapidly in recent years. The microbiological safety and quality of poultry meat are equally important to producers, retailers and consumers, and both involve microbial contaminants on the processed product (Mead, 2004).

However, the high contents of fat makes gizzards tasty with pleasant flavour and popular to the consumer. Depending on the cultural context, offal's may be considered as byproducts or as delicacies that command a high price.

Therefore, the main aim of this research work was to evaluate the physiochemical and organoleptic characteristics of poultry burgers containing different substituted of gizzard, heart, liver, skin and fat. The changes in physiochemical and organoleptic characteristics of poultry burgers during frozen storage for six months were also evaluated.

\section{MATERIALS AND METHODS}

\section{Materials}

Chicken by-products (gizzard, heart, liver, skin and fat)

Chicken thigh meat, gizzard, heart, liver, abdominal fat and skin of broiler chicken were obtained from supermarket in Zagazig city, Sharkia Governorate, Egypt. They were washed by tap water, drained and packed separately in polyethylene bags then, stored in frozen at (-18 $\pm 1^{\circ} \mathrm{C}$ ) until used. They were thawed and minced with $8 \mathrm{~mm}$ plate in a meat mincer (Mado Shop Mincer Junior, Germany) immediately before use.

\section{Spices}

Cumin, cubeb, nutmeg, cardamom, clove and celery were obtained from supermarket in, Zagazig city, Sharkia Governorate, Egypt.

\section{Methods}

\section{Preparation of poultry burger}

Chicken burger samples were prepared and divided into 8 equal proteins which have been replaced with different additives shown in Table 1. The chicken mixture was formed manually using a patty maker to obtain round tablets, $10 \mathrm{~cm}$ diameter and $0.5 \mathrm{~cm}$ thickness. The burgers were packed in polyethylene bags in the foam dish.

\section{Analytical methods \\ Chemical composition}

The moisture, protein, fat, carbohydrates and total ash content were determined for burger samples according to AOAC (2000).

\section{pH value}

The $\mathrm{PH}$ value was determined according to the method mentioned by AOAC (2005).

\section{Lipid extraction}

The lipids of poultry burger samples were extracted using n-hexane as a solvent according to the method of Association of Official Analytical Chemist (1990). 
Table 1. The formulation of various suggested chicken burger treatments

\begin{tabular}{lcccccccc}
\hline Ingredient (g) & \multicolumn{7}{c}{ Treatment } \\
\cline { 2 - 8 } & CB & GHB & SB & FB & SFB & GB & HB & LB \\
\hline Chicken thighs & 3000 & 2400 & 2400 & 2400 & 2400 & 2400 & 2400 & 2400 \\
Gizzards + heart (1:1) & - & 600 & - & - & - & - & - & - \\
Gizzards & - & - & - & - & - & 600 & - & - \\
Heart & - & - & - & - & - & - & 600 & - \\
Liver & - & - & - & - & - & - & - & 600 \\
Fat & - & - & - & 600 & 300 & - & - & - \\
Skin & - & - & 600 & - & 300 & - & - & - \\
Black pepper & 15 & 15 & 15 & 15 & 15 & 15 & 15 & 15 \\
Salt & 45 & 45 & 45 & 45 & 45 & 45 & 45 & 45 \\
Spices & 15 & 15 & 15 & 15 & 15 & 15 & 15 & 15 \\
\hline
\end{tabular}

CB: control burger sample. GHB: chicken burger substuted with gizzards theart. SB: chicken burger substuted with skin. FB: chicken burger substuted with abdominal fats. SFB: chicken burger substuted with skin and abdominal fats. GB: chicken burger substuted with gizzards. HB: chicken burger substuted with heart. LB: chicken burger substuted with liver.

\section{Thiobarbituric acid (TBA) test}

Thiobarbituric acid value was measured according to the method described by Fernandez et al. (2005).

\section{Water holding capacity (WHC)}

Water holding capacity (WHC) was measured in burger samples by a centrifugation method described by Serdaroğl (2006).

\section{Cooking properties of chicken burger samples}

Cooking yield, fat and moisture retention were determined as described by AlessonCarbonell et al. (2005).

\section{Cooking loss of chicken burger samples}

Cooking loss (\%) was calculated as described by AOAC (2000).

After grilling on hot plate with little sunflower oil at 110 -c for min.

Cooking loss $(\%)=$

$$
\frac{\text { Fresh burger weight }- \text { cooked burger }}{\text { Fresh burger weight }} \times 100
$$

\section{Sensory Evaluation}

Sensory analysis was done with hedonic test as described by Trindade et al. (2009).

\section{Statistical Analysis}

Three trials were conducted for each experiment and samples were analyzed in duplicate. The data recorded were analyzed using SPSS version 10.0 of windows (SPSS, Chicago, USA). One way analysis of variance (ANOVA) was applied on all parameters analyzed. The data were tabulated and significant effects were tested using the least significant difference (LSD) test (Snedecor and Cochran, 1986).

\section{RESULTS AND DISCUSSION}

\section{Chemical Composition}

The chemical evaluation of chicken meat byproducts gives an idea about the nutritive value of that food (El-Arby, 2004).

Results presented in Table 2 show that the $\mathrm{pH}$ values were found to varied and ranged from 5.8-6.79. 
The highest protein content $(15.2 \%)$ in Table 2 was presented in liver part followed by heart $(14.12 \%)$ and thigh (14.51\%). Moreover, heart and thigh parts showed the highest moisture content and was found to be $75.81 \%$ and $75.37 \%$, respectively.

Table 3 Shows the moisture contents in different burger samples, the result of moisture content of manufactured chicken burger was decreased for all investigated burger samples. Changes in such parameter reflect the extent of water holding capacity (WHC) of meat and directly affect yield of meat during cooking. The WHC contents of burger samples in Table 3, showed that the (FB) contained the highest value and ranged $(68.87 \%)$ while, the (LB) was contained the lower value and ranged $(67.78 \%)$ as presented in Table 3. The highest cooking loss content was for the (LB) while, the lower cooking loss content was for the (CB).

Results presented in Table 4 show the protein content in burger samples during frozen storage for 6 months. It is clear that the decrease in protein content of all investigated samples was found to be around $17 \%$. This finding may be due to addition of chicken by-product as a source of protein. From these results, it could be concluded that the loss in total protein content might be attributed to partially breakdown of proteins by proteolytic enzymes which are not completely inactivated during storage as well as due to the loss of nitrogen compounds, either as volatile substances caused by microbial effect or separated in drip during thawing the frozen meat samples (Miller et al., 1980).

Results obtained from Table 4 showed that the $\mathrm{pH}$ value was decreased by 1.2 -fold for $\mathrm{CB}$ sample during storage but still within the permissible limits of the Egyptian Organization for Standardization and Quality Control (EOSQC, 2005). The decrease in $\mathrm{pH}$ may be attributed to the breakdown of glycogen to the formation of lactic acid.

Fat content did not exceed 30\% (maximum amount stipulated in the FAO (2014) in all tested burger samples. The fat contents was significantly decreased in the various burger samples, with the (SFB) contained the highest value (followed by (FB) $(3.68 \%)$ then (SB) $(3.66 \%)$ followed by and finally (CB) which contained the least value (2.97\%) after 6 months of storage.

Table 6 shows the colour attributes (lightness, L*; redness, a*and yellowness, $b^{*}$ ) ofburger samples after storage for 6 months. By the end of storage the $L^{*}, a^{*}$ and $b^{*}$ values of chicken by products was ranged from 24.25 to 42.24 for lightness, 3.01 to 9.93 for redness and 5.23 to 14.40 for yellowness.

In addition, the $\mathrm{L}^{*}(39.20)$ and $\mathrm{a}^{*}(8.22)$ values lightly were higher in case of sample (BSF) and (GB), respectively. The $\Delta \mathrm{E}$ value of all investigated samples was almost around 45.10 with regard to the sample (BSF) that had higher value $\Delta \mathrm{E}$ (48.30) by the end of storage.These variations may be due to the addition of chicken by- products to the burger.

\section{Organoleptic Examination}

Organoleptic examination is one of the main indicators, which measure quality of most foods. The results in Table 7 represented the organoleptic properties of chicken burger substituted with different chicken by-products including colour intensity, firmness, flavour, juiciness and overall acceptability. There were significant decrease $(p<0.05)$ in taste, juiciness, flavour and over all acceptability between all investigated samples. Meanwhile, the colour intensity was found to be reduced in all investigated samples. This may be due to the freezing and thawing processes which had a significant effect on colour and decrease in $\mathrm{pH}$ value which lead to the paleness of the colour. In general, samples (GHB) and (SB) had the highest score (9.5-9.6) of colour, taste juiciness, flavour and overall acceptability abtained by panliests.

These results agree with Darwish et al. (2011) who, used a different non meat ingredient (sweet potatoes) in formulation of beef burger and freezing storage at $-18^{\circ} \mathrm{C}$ for 12 weeks induced significantly reduced $(\mathrm{p}<0.05)$ the sensory panel scores for all the investigated parameters. The most pronounced effect was the effect on the flavour and overall acceptability. These results disagree with Kumar et al. (2014). They found that the organoleptic attributes, as appearance, flavour, texture and overall palatability were not affected due to frozen storage except juiciness which decreased significantly after three months of storage. 
Zagazig J. Agric. Res., Vol. 45 No. (1) 2018

Table 2. Physicochemical compositions of chicken thighs and chicken by-products used for making chicken burger

\begin{tabular}{lcccccc}
\hline Chemical composition & Thigh & Heart & Gizzard & Liver & Fat & Skin \\
\hline Moisture (\%) & 75.37 & 75.81 & 76.00 & 77.00 & 32.5 & 51.02 \\
Fat (\%) & 3.15 & 3.60 & 3.84 & 2.90 & 62.06 & 37.80 \\
Protein (\%) & 14.51 & 14.12 & 13.55 & 15.2 & 2.12 & 8.22 \\
Carbohydrates (\%) & 3.43 & 3.77 & 3.68 & 3.50 & 3.03 & 2.52 \\
Ash (\%) & 3.54 & 2.70 & 2.98 & 1.40 & 0.29 & 0.46 \\
pH & 6.18 & 6.50 & 6.70 & 5.80 & 6.79 & 6.60 \\
\hline
\end{tabular}

Table 3. Change in moisture, WHC and cooking loss in chicken burger samples as effected by frozen storage

\begin{tabular}{lccccccccc}
\hline & \multicolumn{3}{c}{ Moisture (\%) } & \multicolumn{3}{c}{ (WHC) (\%) } & \multicolumn{3}{c}{ Cooking loss (\%) } \\
\cline { 2 - 10 } Sample & \multicolumn{3}{c}{} & \multicolumn{3}{c}{ Freezing storage period (month) } \\
\cline { 2 - 10 } & $\mathbf{0}$ & $\mathbf{3}$ & $\mathbf{6}$ & $\mathbf{0}$ & $\mathbf{3}$ & $\mathbf{6}$ & $\mathbf{0}$ & $\mathbf{3}$ & $\mathbf{6}$ \\
\hline CB & 72.61 & 71.09 & 68.74 & 54.18 & 58.76 & 67.91 & 35.11 & 36.17 & 37.29 \\
GHB & 72.58 & 71.12 & 68.68 & 54.17 & 58.74 & 67.88 & 35.09 & 36.15 & 37.31 \\
SB & 70.93 & 69.35 & 66.47 & 56.09 & 62.64 & 68.85 & 34.97 & 36.14 & 37.32 \\
FB & 70.93 & 69.35 & 66.47 & 56.16 & 62.66 & 68.87 & 35.03 & 37.18 & 37.88 \\
SFB & 70.94 & 69.37 & 66.48 & 56.23 & 61.71 & 68.19 & 35.02 & 37.16 & 37.91 \\
GB & 72.54 & 71.09 & 68.70 & 54.15 & 58.73 & 67.85 & 35.01 & 37.15 & 37.91 \\
HB & 72.55 & 71.11 & 68.72 & 54.21 & 58.80 & 67.93 & 35.01 & 37.15 & 37.93 \\
LB & 72.59 & 71.12 & 68.76 & 54.03 & 58.66 & 67.78 & 34.98 & 37.11 & 37.95 \\
\hline
\end{tabular}

CB: control burger sample. GHB: chicken burger substuted with gizzards theart. SB: chicken burger substuted with skin. FB: chicken burger substuted with abdominal fats. SFB: chicken burger substuted with skin and abdominal fats. GB: chicken burger substuted with gizzards. HB: chicken burger substuted with heart. LB: chicken burger substuted with liver. 
Table 4. Change in protein, $\mathrm{pH}$ and Ash contents in chicken burger samples as effected by frozen storage

\begin{tabular}{lccccccccc}
\hline Sample & \multicolumn{3}{c}{ Protein (\%) } & \multicolumn{3}{c}{ pH } & \multicolumn{5}{c}{ Ash (\%) } \\
\hline & \multicolumn{3}{c}{ Freezing storage period (month) } \\
\hline 0 & $\mathbf{3}$ & $\mathbf{6}$ & $\mathbf{0}$ & $\mathbf{3}$ & $\mathbf{6}$ & $\mathbf{0}$ & $\mathbf{3}$ & $\mathbf{6}$ \\
\hline CB & 23.11 & 21.17 & 19.09 & 6.73 & 6.41 & 5.88 & 0.07 & 2.6 & 4.5 \\
GHB & 23.15 & 21.20 & 19.12 & 6.67 & 6.29 & 5.75 & 0.06 & 2.44 & 4.65 \\
SB & 21.26 & 19.27 & 17.06 & 6.86 & 6.46 & 5.91 & 0.39 & 1.59 & 4.5 \\
FB & 21.23 & 19.15 & 17.62 & 6.91 & 6.46 & 5.94 & 0.37 & 1.68 & 4.11 \\
SFB & 21.24 & 19.21 & 17.63 & 6.89 & 6.45 & 5.93 & 0.4 & 1.61 & 4.5 \\
GB & 23.22 & 21.30 & 19.10 & 6.69 & 6.32 & 5.76 & 0.06 & 2.14 & 4.03 \\
HB & 23.14 & 21.18 & 19.92 & 6.65 & 6.28 & 5.72 & 0.09 & 2.44 & 4.33 \\
LB & 23.16 & 21.23 & 19.14 & 6.64 & 6.26 & 5.70 & 0.05 & 2.78 & 4.47 \\
\hline
\end{tabular}

CB: control burger sample. GHB: chicken burger substuted with gizzards theart. SB: chicken burger substuted with skin. FB: chicken burger substuted with abdominal fats. SFB: chicken burger substuted with skin and abdominal fats. GB: chicken burger substuted with gizzards. HB: chicken burger substuted with heart. LB: chicken burger substuted with liver.

Table 5. Change in fat and Thiobarbituric acid (TBA) contents in chicken burger samples as effected by frozen storage

\begin{tabular}{|c|c|c|c|c|c|c|}
\hline \multirow[t]{3}{*}{ Sample } & \multicolumn{3}{|c|}{ Fat $(\%)$} & \multicolumn{3}{|c|}{ Thiobarbituric acid (TBA) } \\
\hline & \multicolumn{6}{|c|}{ Frozen storage period (month) } \\
\hline & $\mathbf{0}$ & 3 & 6 & $\mathbf{0}$ & 3 & 6 \\
\hline $\mathbf{C B}$ & 3.19 & 3.11 & 2.97 & - & 0.616 & 1.19 \\
\hline GHB & 3.15 & 3.03 & 2.87 & - & 0.614 & 1.14 \\
\hline SB & 3.95 & 3.80 & 3.66 & - & 0.739 & 1.49 \\
\hline FB & 3.98 & 3.83 & 3.68 & - & 0.742 & 1.50 \\
\hline SFB & 3.97 & 3.82 & 3.69 & - & 0.743 & 1.52 \\
\hline GB & 3.16 & 3.04 & 2.84 & - & 0.613 & 1.13 \\
\hline HB & 3.13 & 3.01 & 2.84 & - & 0.611 & 1.12 \\
\hline LB & 3.11 & 2.97 & 2.82 & - & 0.608 & 1.1 \\
\hline
\end{tabular}

CB: control burger sample. GHB: chicken burger substuted with gizzards theart. SB: chicken burger substuted with skin. FB: chicken burger substuted with abdominal fats. SFB: chicken burger substuted with skin and abdominal fats. GB: chicken burger substuted with gizzards. HB: chicken burger substuted with heart. LB: chicken burger substuted with liver. 
Zagazig J. Agric. Res., Vol. 45 No. (1) 2018

Table 6. Hunter colour parameters of chicken burger containing different combinations of chicken by-products and chicken burger samples after storage for 6 months

\begin{tabular}{lcccccc}
\hline Sample & $\mathbf{L}^{*}$ & $\mathbf{a}^{*}$ & $\mathbf{b}^{*}$ & $\mathbf{C}^{*}$ & $\mathbf{h}^{*}$ & $\mathbf{\Delta} \mathbf{E}$ \\
\hline Chicken thigh & 24.25 & 4.54 & 5.23 & 6.93 & 49.00 & 85.30 \\
Heart & 21.76 & 6.99 & 7.42 & 10.20 & 46.70 & 87.00 \\
Gizzard & 24.32 & 7.00 & 5.33 & 8.80 & 37.30 & 41.90 \\
Liver & 21.22 & 9.93 & 7.89 & 12.70 & 38.50 & 45.20 \\
Abdominal fats & 39.21 & 3.01 & 14.40 & 14.70 & 78.20 & 49.20 \\
Skin & 42.24 & 3.51 & 11.33 & 11.80 & 72.70 & 46.30 \\
CB & 35.94 & 4.64 & 10.43 & 11.40 & 66.00 & 45.10 \\
GHB & 30.20 & 8.24 & 10.08 & 13.00 & 50.80 & 45.00 \\
SB & 35.41 & 4.77 & 11.90 & 12.80 & 68.20 & 46.60 \\
FB & 38.54 & 3.23 & 12.75 & 13.20 & 75.80 & 47.60 \\
SFB & 39.20 & 4.35 & 13.55 & 14.30 & 72.30 & 48.30 \\
GB & 30.28 & 8.22 & 10.5 & 13.30 & 51.90 & 45.40 \\
HB & 30.15 & 7.99 & 10.11 & 12.90 & 51.70 & 45.00 \\
LB & 30.11 & 8.35 & 10.21 & 13.20 & 50.70 & 45.10 \\
\hline
\end{tabular}

CB: control burger sample. GHB: chicken burger substuted with gizzards theart. SB: chicken burger substuted with skin. FB: chicken burger substuted with abdominal fats. SFB: chicken burger substuted with skin and abdominal fats. GB: chicken burger substuted with gizzards. HB: chicken burger substuted with heart. LB: chicken burger substuted with liver.

Table 7. Organoleptic evaluation of chicken burger containing different combinations of chicken by-products

\begin{tabular}{lcccccccc}
\hline Characteristics & \multicolumn{7}{c}{ Treatment } \\
\cline { 2 - 9 } & CB & GHB & SB & FB & SFB & GB & HB & LB \\
\hline Colour & $9.7 \mathrm{a}$ & $9.6 \mathrm{a}$ & $9.2 \mathrm{a}$ & $9.1 \mathrm{a}$ & $9.1 \mathrm{~b}$ & $9.5 \mathrm{~b}$ & $9.6 \mathrm{a}$ & $9.6 \mathrm{a}$ \\
Taste & $9.4 \mathrm{a}$ & $9.5 \mathrm{a}$ & $8.8 \mathrm{~b}$ & $8.5 \mathrm{~b}$ & $8.6 \mathrm{~b}$ & $9.6 \mathrm{a}$ & $9.6 \mathrm{a}$ & $9.1 \mathrm{~b}$ \\
Juiciness & $9.7 \mathrm{a}$ & $9.5 \mathrm{a}$ & $8.9 \mathrm{~b}$ & $8.9 \mathrm{~b}$ & $8.9 \mathrm{~b}$ & $9.5 \mathrm{a}$ & $9.5 \mathrm{a}$ & $9.3 \mathrm{a}$ \\
Flavour & $9.5 \mathrm{a}$ & $9.6 \mathrm{a}$ & $8.9 \mathrm{~b}$ & $8.8 \mathrm{~b}$ & $8.9 \mathrm{~b}$ & $9.5 \mathrm{a}$ & $9.5 \mathrm{a}$ & $9.3 \mathrm{~b}$ \\
Overall acceptability & $9.5 \mathrm{a}$ & $9.6 \mathrm{a}$ & $8.7 \mathrm{~b}$ & $8.5 \mathrm{~b}$ & $8.4 \mathrm{~b}$ & $9.6 \mathrm{a}$ & $9.6 \mathrm{a}$ & $9.1 \mathrm{a}$ \\
\hline
\end{tabular}

$\overline{\mathrm{CB}}$ : control burger sample. GHB: chicken burger substuted with gizzards theart. SB: chicken burger substuted with skin. FB: chicken burger substuted with abdominal fats. SFB: chicken burger substuted with skin and abdominal fats. GB: chicken burger substuted with gizzards. HB: chicken burger substuted with heart. LB: chicken burger substuted with liver.

Values in the same row followed by different letters are significantly different: $* \mathrm{P} \leq 0.05$ 
These results also disagree with Kamel (2015) who revealed that $6^{\text {th }}$ month storage at freezing temperature $\left(-18^{\circ} \mathrm{C}\right)$ was the longest period for which broiler chicken fillets may be found to have impeccable sensory properties specially colour, odour and flavour and still within the acceptable range. These results are confirmed by Abu-Ruwida et al. (1996) who reported acceptability of chicken meat after 6-9 months of storage at $-18^{\circ} \mathrm{C}$ as there was no significance of the sensory parameter scores of the examined samples $(p>0.05)$.

\section{Conclusion}

Based on the results, the use of chicken gizzards is encouraged to produce meat products such as burger, at commercial scale. As the broiler chickens gizzards cost less than $50 \%$ of the beef price, and since the results of the present study indicate that the burger products made from gizzards and heart are safe acceptable by the panelists. Therefore, it is highly recommended to incorporate chicken gizzards and heart at a level of $20 \%$.

\section{REFERENCES}

Abu-Ruwida, A.S., W.N. Sawaya, B.H. Dashti, Z.H. Baroon and H.A. Al-Othman (1996). Microbiological shelf-life and quality of frozen broiler chickens stored under simulated market temperatures. Fleischwirtschaft, 76 (8): 827-830.

Alesson-Carbonell, L.J., F. Lopes, J.A.P. Alvarez and V. Kuri (2005). Characteristics of beef burger as influenced by various types of lemon albedo. Innov. Food Sci. Emer. Technol., $6: 247-255$.

AOAC (2000). Official Methods of Analysis of the Association of Official Analytical Chemists. $17^{\text {th }}$ Ed. Gaithersburg, MD, USA: AOAC.

AOAC (2005). Official Method of Analysis. Association of Official Analytical Chemists, $16^{\text {th }}$ Ed. Gaithersburg, DC, USA.

Association of Official Analytical Chemist (1990). Official Methods of Analysis of the Association of Official Analytical Chemists $\left(15^{\text {th }}\right.$ Ed.). Arlington, va, usa: aoac.
Darwish, A.M., M.L. Adel, A.A. Osama and A.A. Abdelsalam (2011). Effect of some nutritional additives on the quality and formulation cost of beef burger. World J. Dairy and Food Sci., 6 (2): 180-188.

El-Arby, G.M. (2004). Studies on some meat products. M.Sc. Thesis Fac. Agric., Zagagig Univ., Egypt.

Elkhatim, M.I., A. Abdelmageed, E. Sulieman, O. Hyder, H.O. Abdalla and G.E. Salih (2014). Effects of incorporating poultry's gizzards and abdominal fat in the quality of burger meat product. J. Microbiol. Res., 4 (2): 68-71.

EOSQC (2005): Standards of poultry meat products, Egyptian standard for frozen meat. Ministry of Industry No 3493/2005. Cairo, Egypt.

FAO (2014). Food and Agriculture Organization. The role of poultry in human nutrition. Available at: WWW. FAO. Org/docrep/ 013/ al713e/al713e00.

Fernandez, L.J., N. Zhi, C.L. Aleson, J.A. PerezAlvarez and V. Kuri (2005). Antioxidant and antibactetial activities of natural extracts: Application in beef meatballs. Meat Sci., 69 : 371-380.

Grzeskowiak, E., M. Fabian and D. Iisiak (2001). Evaluation of the phosphorus and the quality of meat and meat products available on the domestic market. Żywność. Nauka. Technologia. Jakość, 2: 160-170.

Kamel, A.S. (2015). Effect of Preservation on Chicken Fillets Quality. Thesis, Meat Hygiene. Pac., Vet. Med., Zagazig Univ., Egypt.

Kumar, S., U.K. Pal, P.K. Mandal and C. Das (2014). Changes in the quality of obtained from different sources during frozen storage. Explor. Anim. Med. Res., 1(4): 95-100.

Lee, K.T. and T.A.A. Foglia (2000). Fractionation of poultry fat triacylglycerols. Synthesis of structured lipids with immobilized lipases J. Food Sci., 65 (5): 826-831.

Mead, G.C. (2004): Microbiological quality of poultry meat: A Review. Braz. J. Poult. Sci., $6(3): 135-142$. 
Maiti, A.K. and S.S. Ahlawat (2011). Effect of Natural Tenderizers on Physiochemical Properties of Chicken Gizzards and Goat Heart. Ame. J. Food Technol., 6 (1): 80-86.

Miller, W.R., C.A. Taylor and J.C. West (1980). Focused versus broad spectrum behavior therapy for problem drinkers. J. Consulting and Clin. Psychol., 48 : 590-601.

Serdaroğl, M. (2006). Improving low fat meat ball characteristics by adding whey powder. Meat Sci., 72 (1):155-163.

Smith, D.M. (2001). Functional Properties of Muscle Proteins in Processes Poultry Products in Poultry Meat Processing, Ed. By Sams AR. Crc Pres.
Snedecor, G.W. and W.C. Cochran (1986). Statistical Methods. $8^{\text {th }}$ Ed., Iowa Univ. Press, Ames, Iowa, USA.

Trindade, R.A., A. Lima, E.R. Andrade-Wartha, A.M. Oliveira de Silva, J. Mancini-Filho and A.L.C.H. Villavicencio (2009). Consumer's evaluation of the effects of gamma irradiation and natural antioxidants on general acceptance of frozen beef burger. Rad. Physics and Chem., 78 (4): 293-300.

Yashoda, K.P., M.N. Sachindra, P.Z. Sakhare and D.N. Rao (2001). Microbiological quality of broiler poultry carcasses processed hygienically in a small scale poultry processing unit. J. Food Quality, 24 (3): 249259.

\section{الخصائص الكيماوية والفيزيقية والحسية لبرجر الدجـاج المجمد المستبدل بالمنتجات الثانوية للاجاج}

سمر محمود أحمد عيد - محمد عبدالحميد ربيع - جيهان عبدالله الثوربجى - شريف عيد عبدالمقصود النمر

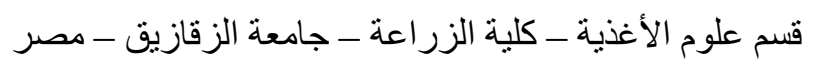

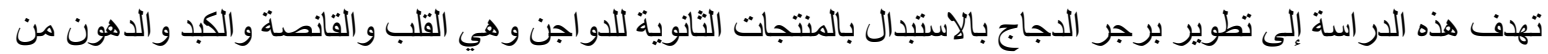

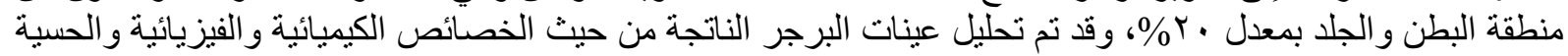

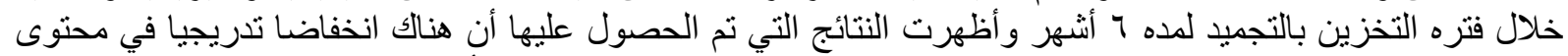

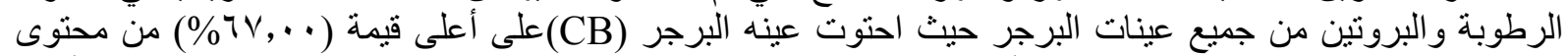

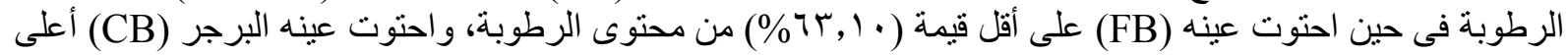

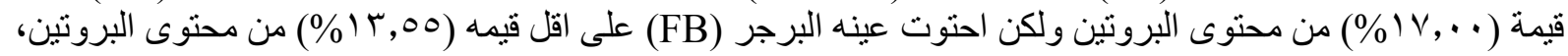

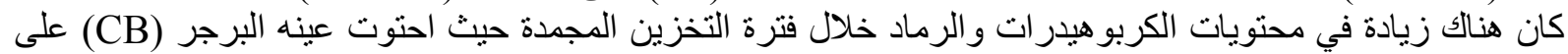

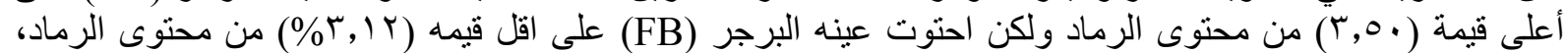

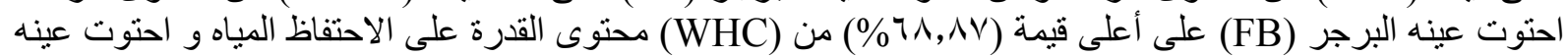

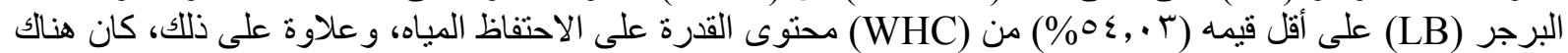

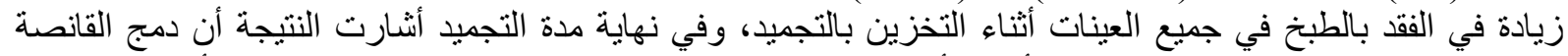

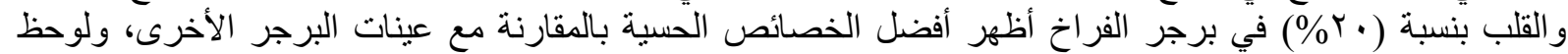

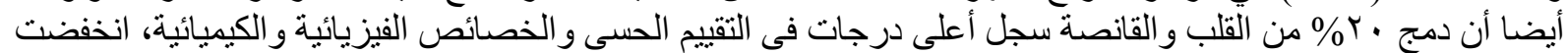
الدرجات لجميع الصفات الحسية بشكل ملحوظ مع تقدم فترة التخزين. 